\title{
Pharmacognostical and Phytochemical Evaluation Leaves Ex- tract of Garcinia daedalanthera Pierre
}

\author{
Sarah Zielda Najib', Meiliza Ekayanti', Lia Ardiana', Rani Sauriasari', Berna Elya ${ }^{2}$ \\ 'Faculty of Pharmacy, University of Indonesia, Depok, 16424, INDONESIA. \\ 2Laboratory of Phytochemistry and Pharmacognosy, Faculty of Pharmacy, Universitas Indonesia, Depok, 16264, INDONESIA.
}

\begin{abstract}
Background: Garcinia daedalanthera is an Indonesian plant where commonly found in Sulawesi, Indonesia and spread out in the forest. Garcinia daedalanthera is one of Clusiaceae family that have been scientifically proven to provideantidiabetic and antioxidant activity but never been examined in pharmacognosy parameters. Pharmacognostical parameters of the leaves were studied with the aim of drawing the pharmacopoeial standards for this species. Methods: The present study was aimed to analysis the pharmacognosy of Garcinia daedalanthera including leaf morphology, microscopic characteristics, physicochemical parameters, phytochemical study, contaminant analysis and FTIR spectrum analysis. Results: The phytochemical analysis revealed the presence of flavonoids, saponins, tannin, steroids and phenols. The moisture content was $2.35 \%$, total ash $2.51 \%$, acid insoluble ash $0.05 \%$, total flavonoid and phenolic content were found to be $3.121 \%$ and $14.36 \%(\mathrm{w} / \mathrm{w}$ ). The level of Arsenic (As), Cadmium (Cd) and lead $(\mathrm{Pb})$ were found under the limit $(0.357 \mathrm{ppm})$ and the extract of
\end{abstract}

leaves Garcinia daedalanthera Pierre does not contain bacterial contamination. Conclusion: The data generated from this study would help in standardization for pharmacopoeial and prevent adulteration of leaves extract of Garcinia daedalanthera Pierre and the authentic plant material can be explored for its pharmacological.

Key words: Standardization, Garcinia daedalanthera extract, FTIR, Macromicroscopy study, preliminary screening, pharmacognosy study

Correspondence :

Berna Elya

Laboratory of Phytochemistry and Pharmacognosy, Faculty of Pharmacy,

Universitas Indonesia, Depok, 16264, INDONESIA.

Phone: +62-21-7270031

Email: berna@farmasi.ui.ac.id

DOI: 10.5530/jyp.2017.1s.16

\section{INTRODUCTION}

Indonesia has the second biggest biodiversity in the world expressed by a high number of indigenous medicinal plants. ${ }^{1}$ Indonesia has many plants that could serve as anti-diabetes and anti-obesity agents. ${ }^{2}$ In Indonesia, people use Garcinia mangostana Linn. as a health supplement for preventing everything from ulcer, diarrhea, fever, hypertension, and obesity to diabetes mellitus. ${ }^{3}$ Garcinia is considered the most diverse and bountiful genus of the Clusiaceae family. ${ }^{4}$ Garcinia mangostana Linn. has been discovered to possess a wide range of biological activities, with antiinflammatory, anti-tumor, cardioprotective, antidiabetic, antibacterial, antifungal, antiparasitic, antioxidant and antiobesity agents. ${ }^{5}$ Another plant from Garcinia is Garcinia daedalanthera Pierre. Previous research had shown the extract of Garcinia daedalanthera Pierre has $\mathrm{IC}_{50} 2,33 \mu \mathrm{g} /$ $\mathrm{mL}$ as a-glucosidase inhibitor. ${ }^{6}$ A subsequent study showed that Garcinia daedalanthera (GD) has dual effect, as $\alpha$-glucosidase inhibitor and scavenger radical. ${ }^{6,7}$ The results reveal these medicinal plants as having a promising potential, particularly in pharmacology. Therefore, the present study was designed to study the pharmacognostic study of the leaves, phytochemical screening, determination of total phenolic content, total flavonoid, and total tannins, also FTIR spectrum analysis of Garcinia daedalanthera Pierre extract for its standardization.

\section{MATERIALS AND METHODS}

The fresh Leaves of Garcinia daedalanthera were collected and determined by Bogor Botanical Gardens, West Java, Indonesia. Ethanol (BRATACO), kloralhidrat (sigma, Aldrich), quercetin (sigma, Aldrich), tannic acid (sigma, Aldrich), gallic acid (Merck), Folin-Ciocalteu phenol reagent (Merck). The dried leaves were used for the study of macroscopic and microscopical characterization.

\section{Macroscopic and Microscopic Identification}

Fresh and powder of Garcinia daedalanthera's leaf was identified before and after the drying process by using a Microscope IX70. slides of leaf blades and powder of G.daedalanthera were prepared and observed under light microscope. Identification of powder Garcinia daedalanthera's leaf was also done using Field Emission Scanning Electron Microscopy (FE-SEM). The powder Garcinia daedalanthera's was coated with gold for 1 minute before the photographs were taken.

\section{Extraction of Garcinia daedalanthera}

The leaves of Garcinia daedalanthera were collected and cleaned, shade dried at room temperature, coarsely powdered and stored in an air tight glass container. $3 \mathrm{~kg}$ of coarse powder was extracted with ethanol $80 \%$ as the solvent.

\section{Preliminary phytochemical evaluation}

The extracts were subjected to phytochemical tests for plant secondary metabolites, tannins, flavonoids, saponins, steroid, and alkaloids. ${ }^{8}$

\section{Determination of Physico-chemical parameters}

The moisture content, total ash, total acid-insoluble ash, water-soluble extractives, and ethanol-soluble extractives were determined according to the methods recorded in the Farmakope Herbal Indonesia. 


\section{Total phenolic content}

Total phenolic content was analyzed using the Folin-Ciocalteu colorimetric method with some modifications. An aliquot of $0.3 \mathrm{~mL}$ of leaf or bark extract was mixed with Folin-Ciocalteu phenol reagent $(2.25 \mathrm{~mL})$. After $5 \mathrm{~min}, 6 \%$ sodium carbonate $(2.25 \mathrm{~mL})$ was added and the mixture was allowed to stand at room temperature for $90 \mathrm{~min}$. The absorbance of the mixture was measured at $725 \mathrm{~nm}$. Standard calibration curve for gallic acid in the range of $0-200 \mathrm{mg} / \mathrm{mL}$ was prepared in the same manner and results were expressed as mg gallic acid equivalent (GAE) per gram of extract. ${ }^{9}$

\section{Total flavonoid content (TFC)}

Total flavonoid content was determined using the aluminum colorimetric method with some modifications using quercetin as the standard. A calibration curve of quercetin was prepared in the range of $0-200 \mathrm{mg} /$ $\mathrm{mL}$. Briefly, extract $(0.5 \mathrm{~mL})$ and standard $(0.5 \mathrm{~mL})$ were placed in different test tubes and to each $10 \%$ aluminum chloride $(0.1 \mathrm{~mL}), 1 \mathrm{M}$ potassium acetate $(0.1 \mathrm{~mL}), 80 \%$ methanol $(1.5 \mathrm{~mL})$ and distilled water $(2.8$ $\mathrm{mL}$ ) were added and mixed. A blank was prepared in the same manner where $0.5 \mathrm{~mL}$ of distilled water was used instead of the sample or standard, and the amount of aluminum chloride was also replaced by distilled water. All tubes were incubated at room temperature for $30 \mathrm{~min}$. The absorbance was taken at $415 \mathrm{~nm}$. The concentration of flavonoid was expressed as mg quercetin equivalent $(\mathrm{QE})$ per gram of extract. ${ }^{9}$

\section{Total Tannin (TT) content}

Using tannic acid as a standard for TT content. The sample was analyzed followed Folin-Denis method. ${ }^{10}$

\section{Contamination Analysis}

Contaminant analysis was determined by measuring heavy metal content using AAS method, ${ }^{11}$ and pathogenic microbial contamination such as E. coli, Salmonella sp.,and Pseudomonas aeruginosa.

\section{Examination of Fourier Transform Infrared Spectroscopy (FTIR)}

The powdered extract was analyzed by KBr-FTIR spectroscopy. KBr-FTIR spectra were recorded with a Nicolet 5700 instrument. A 2 mg aliquot of powdered sample was mixed with $200 \mathrm{mg} \mathrm{KBr}$ in an agate mortar. Measurement range was $4000-400 \mathrm{~cm}$. The preparation of $\mathrm{KBr}$ pellets relied on a standardized. The background was recorded each time before the measurement and subtracted automatically by the software.

\section{RESULTS}

\section{Macroscopic and Microscopic identification}

The plant of Garcinia daedalanthera Pierre has approximately 4 meters of height and the leaves are opposite each petiole, has $25-35 \mathrm{~cm}$ long and width around $15-20 \mathrm{~cm}$, shaped ovate to lanceolate with serrate margin. The color of the leaves is blackish green and appearance, odor and taste of the leaves are rough and scabrous, nonaromatic and respectively (Figure 1). The flower of Garcinia daedalanthera Pierre is white with distinctive fragrance. Organoleptic study of the leaf powder of Garcinia daedalanthera revealed that it was green to brown in color and has an aromatic odor and a bitter taste.

The transverse section of the leaf In Figure 2 showed the xylem and phloem. Phloem surrounds the xylem in both (Figure 2a, 2b). Vessel elements of different shape and size were abundant in the powder .Some vessel elements were short wide and barrel shaped. Some are narrow and long. The vessel elements had simple wide horizontal perforated plate.
Tracheids were sparse and less frequent. They were long narrow cylindrical cells with abundant lateral wall pits (Figure 2d, 2e and 2f).

Both the upper and lower epidermis (Figure 4 and 5) same as seen stomata and oxalate crystals, but on the upper epidermis (Figure 5) stomata number less than the lower epidermis. Pentagonal-shaped form of the epidermal cells. Calcium oxalate crystals were sparsely distributed in both epidermis and crystals oxalate were mostly prismatic

The stomata were paracytic type. Equal size and shape of parallel subsidiary cells and lateral on each guard cell (Figure 6) on both surfaces of the leaf. The epidermal cels are variable in shape; they are narrowly rectangular, slightly lobed or squarish and some of the epidermal cells are elongated, narrow and canal like. The Tracheids were long narrow cylindrical cells with abudant lateral wall pits (Figure 7).

The phytochemical screening revealed of GDE the presence of flavonoids, saponins, tannin, steroids and phenolic groups (Table 1). The phytochemical compounds detected are known to have medicinal importance. For example, Tannins, according to research, are known to have antibacterial, ${ }^{12}$ antitumor and antiviral activities. ${ }^{13}$ Similarly, steroids derived from plants are known to have cardiotonic effect and also possess antibacterial and insecticidal properties. ${ }^{12,13}$ These phytochemical compounds identified in leaf extract may be responsible for the biological activities shown by G. Daedalanthera and the reason for further testing.
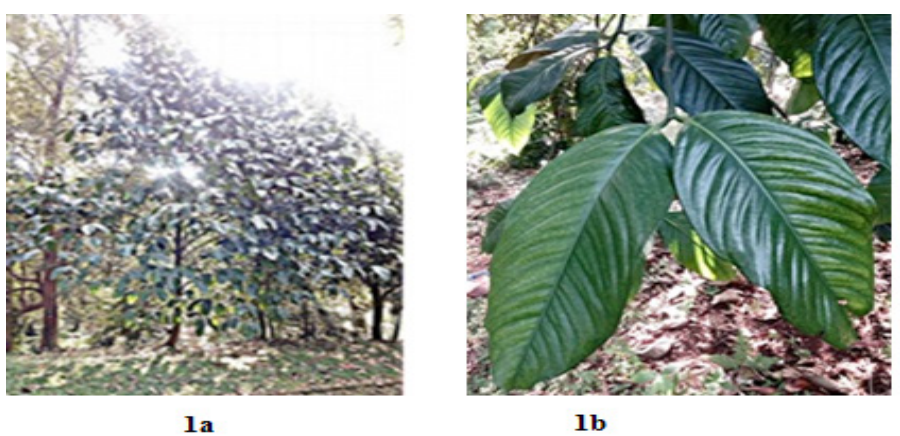

$1 \mathbf{b}$

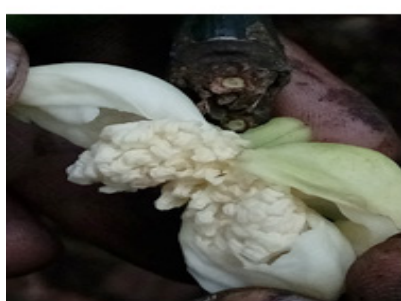

1c

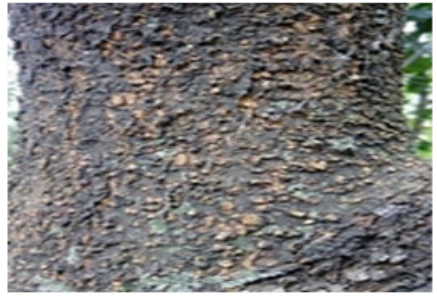

Id

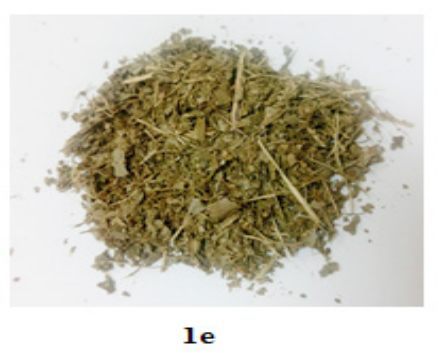

Figure 1: Pharmacognostical studies on GD. 1a. Plant of GD; 1b. Leaf of GD; 1c. Stem bark of GD; 1d. Flower of GD; 1e. Powder of GD. 


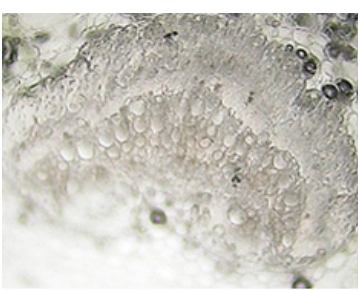

$2 \mathbf{a}$

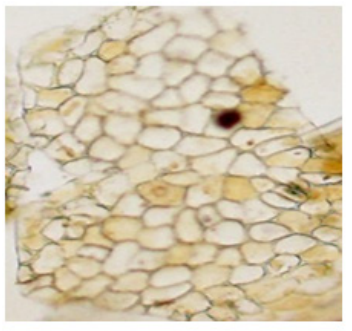

$2 \mathrm{c}$

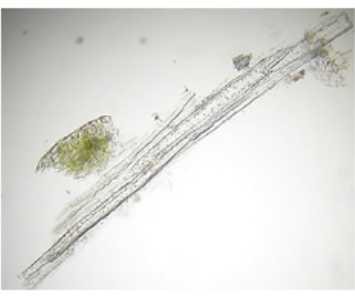

$2 \mathrm{e}$

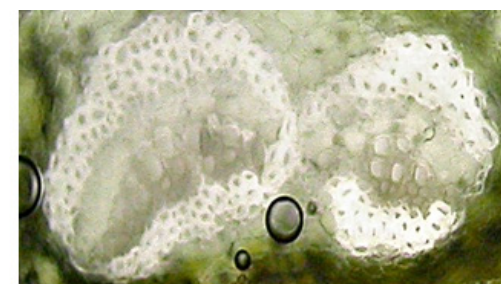

$2 \mathrm{~b}$

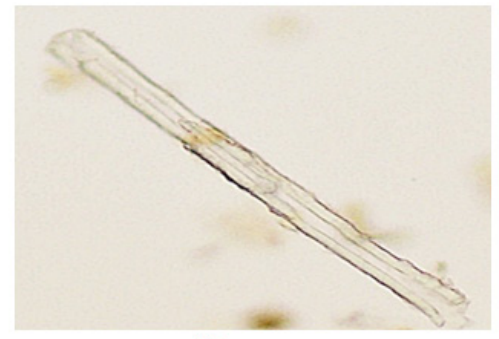

2d

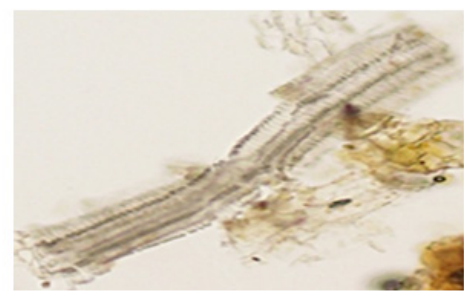

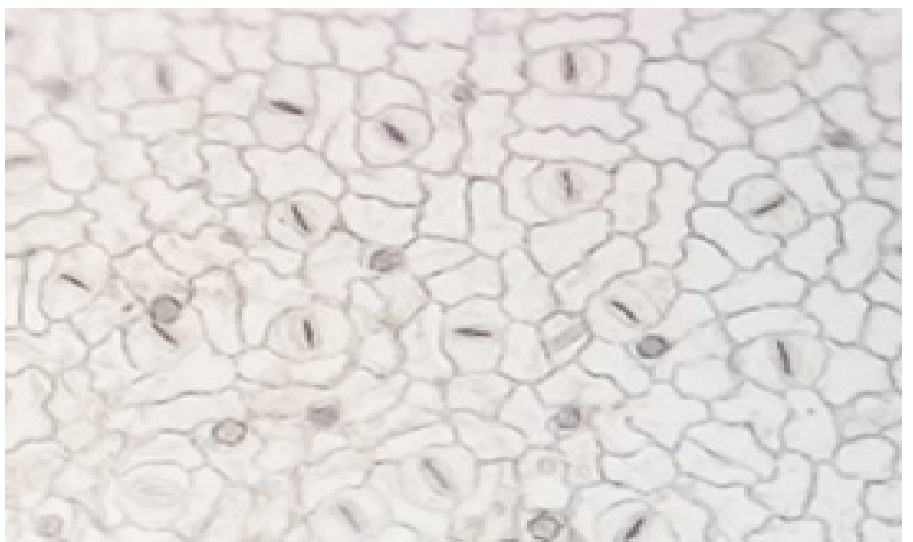

Figure 5: Upper Epidermis.

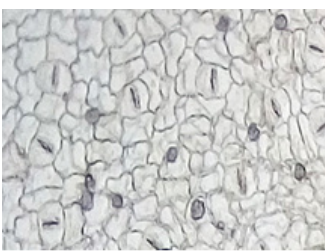

(A)

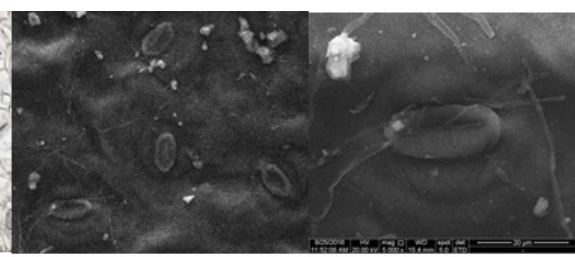

(B)
(C)
Figure 6: Stomata of G. daedalanthera. (A). Microscopical stomata of the powdered leaf; (B). SEMic imaging of Abaxial surface of the leaf; (C). SEMic imaging of Stomata of G. daedalanthera. S; Stomata. SC; Subsidiary cells. EC; Epidermal cells

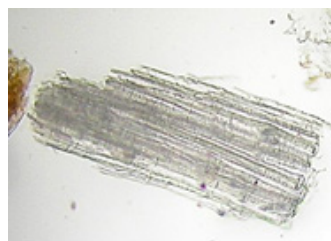

(A)

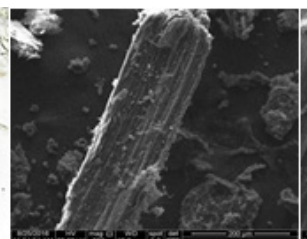

(B)

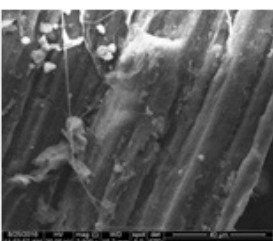

(C)
Figure 7: Tracheid of G.daedalanthera. (A). Microscopical tracheid of G.daedalanthera; (B). SEMic imaging of Abaxial surface of the powder leaf; (C). SEMic imaging of Trachea of $G$. daedalanthera.

\section{Phytochemical parameters}

The results of phytochemical parameters of GDE were given in Table 2. GDE has moisture content is $2.35 \%$, ash content is $2.51 \%$, the acid insoluble ash content is $0.05 \%$, water-soluble extract content is $57.76 \%$ and the alcohol soluble extract content is $42.96 \%$ (Table 2).

The results (Table 3) revealed that GDE has $55.13 \mathrm{mg} \mathrm{GAR} / \mathrm{g}$ total phenolic content, $15.49 \mathrm{mg} \mathrm{QE} / \mathrm{g}$ total flavonoid content and $7.21 \mathrm{mg} / \mathrm{TAE} \mathrm{g}$ total tannin content (Table 3).

The contaminant result in Table 4 showed that GDE has no E.coli, Salmonella sp and Pseudomonas aeruginosa contaminant. And GDE has metal content below limit detection using AAS method (Table 4).

The FTIR spectroscopic study revealed different characteristic peak values with various functional compounds in the extract. In Figure 8, The GDE suggest the presence of carboxylic acid, alkanes, phenol and C-H (aldehydes). The peaks in the range between $3672-3395 \mathrm{~cm}^{-1}$ corresponds to stretching vibrations of $\mathrm{OH}$ groups (From water, alcohols, phenols) as well as from amides. FTIR analysis can be applied to characterize and identify the main biomarkers of food supplement PROMEN by analysis of plant ingredients comparatively with the final product (Figure 8). ${ }^{14}$ 
Table 1: Phytochemical screening of Garcinia daedalanthera extract

\begin{tabular}{cc}
\hline $\begin{array}{l}\text { Preliminary phytochemical screening of Garcinia daedalanthera } \\
\text { extract }\end{array}$ & Garcinia daedalanthera \\
\hline Phytoconstituents & - \\
Alkaloids & - \\
Dregendorff's test & - \\
Mayer's Test & - \\
Wagner's Test & + \\
Flavonoids & + \\
Phenolic groups & + \\
saponins & + \\
steroids & + \\
Tannins & - \\
Triterpenes & - \\
Quinon & +
\end{tabular}

+ present, - absent.

Table 3: Total phenolic and total Flavonoid contents

\begin{tabular}{|cccc|}
\hline Plant Material & $\begin{array}{c}\text { Total phenolic } \\
\text { content }(\mathbf{m g} \\
\text { GAE/g) }\end{array}$ & $\begin{array}{c}\text { Total flavonoid } \\
\text { content }(\mathbf{m g} \\
\text { QE/g) }\end{array}$ & $\begin{array}{c}\text { Total Tannin } \\
\text { content }(\mathbf{m g} \\
\text { TAE/g }\end{array}$ \\
\hline $\begin{array}{l}\text { Leaves GDE (Garcinia } \\
\text { daedalanthera extract })\end{array}$ & $55.13 \pm 3.15$ & $15.49 \pm 3.15$ & 7.21 \\
\hline
\end{tabular}

GAE - Gallic acid equivalent, QE - Quercetin equivalent, TAE - Tannic Acid equivalent

\section{DISCUSSION}

The proper identity of a crude herb or the botanical quality is of key importance in establishing quality of herbal drug. ${ }^{15}$ the morphological and microscopical characteristics is an important factor to guarantee the quality of medicinal materials and clinical efficacy. ${ }^{16}$ Through the macro and microscopical studied can be obtained the identity and Quality control of herbal drugs has traditionally been based on appearance and microscopic evaluation as well as identification of small fragments of crude or powdered herbs and detection of foreign matter and adulterants. ${ }^{15,16}$ Physicochemical parameters and preliminary phytochemical studies will be useful tool along with macroscopical and microscopical characteristics of Garcinia daedalanthera Pierre leaf. ${ }^{22}$ The pharmacognostical studies showed the macroscopical plant, leaf, flower of Garcinia daedalanthera in Figure 1. The microscopical studies showed the microstructure characters of leaf Garcinia daedalanthera in Figure 2. The microscopic showed the paracytic type stomata and shape of trachea of Garcinia daedalanthera in Figure 6. In Figure 3 showed microscopy of xylem and phloem. This microscopic analysis will indeed help to prevaricate the correct species. The phytochemical parameters of GDE were showed in Table 2. the determination of ash content is useful for detecting low-grade products, exhausted drugs and excess of sandy or earthy matter, it is more especially applicable to powdered drugs. ${ }^{17}$ Total ash is the assess of the total amount of material left after burning and includes ash derived from the part of the plant itself and acid-insoluble ash. ${ }^{17}$ The total ash content varies within wide limits for different specimens, and Garcinia daedalanthera has not had reference because this plant is a new plant. The determination of moisture content indicates the percentage of active chemical consituents in crude drugs mentioned on air-dried basis. The moisture content of a drug should be minimized to prevent decomposition of crude drugs either due to chemical change or micro-
Table 2: Phytochemical parameters of Garcinia daedalanthera extract

\begin{tabular}{cc}
\hline \multicolumn{2}{c}{ Phytochemical parameters of Garcinia daedalanthera } \\
Parameters & Garcinia daedalanthera \\
Moisture content & $2.35 \%$ \\
Ash content & $2.51 \%$ \\
Acid insoluble ash content & $0.05 \%$ \\
Water-soluble extract content & $57.76 \%$ \\
Alcohol soluble extract content & $42.96 \%$
\end{tabular}

Table 4: Contaminant Result of leaves Garcinia daedalanthera Ethanolic Extract

\begin{tabular}{cccc}
\hline No. & Parameter Test & Result & Unit \\
1. & $\mathrm{Pb}$ & Under 0.357 & $\mathrm{ppm}$ \\
2. & $\mathrm{As}$ & Under 0.002 & $\mathrm{ppm}$ \\
3. & $\mathrm{Cd}$ & $0.008^{* *}$ & $\mathrm{ppm}$ \\
4. & $\mathrm{Fe}$ & 16.95 & $\mathrm{ppm}$ \\
5. & E. coli & $\mathrm{ND}^{*}$ & Colonies/unit \\
6. & Salmonella sp & $\mathrm{ND}^{*}$ & Colonies/unit \\
7. & Pseudomonas aeruginosa & $\mathrm{ND}^{*}$ & Colonies/unit
\end{tabular}

Description: ${ }^{\star} \mathrm{ND}=$ not detected; ${ }^{*}$ Requirements level of $\mathrm{Cd} £ 0.3 \mathrm{ppm}$

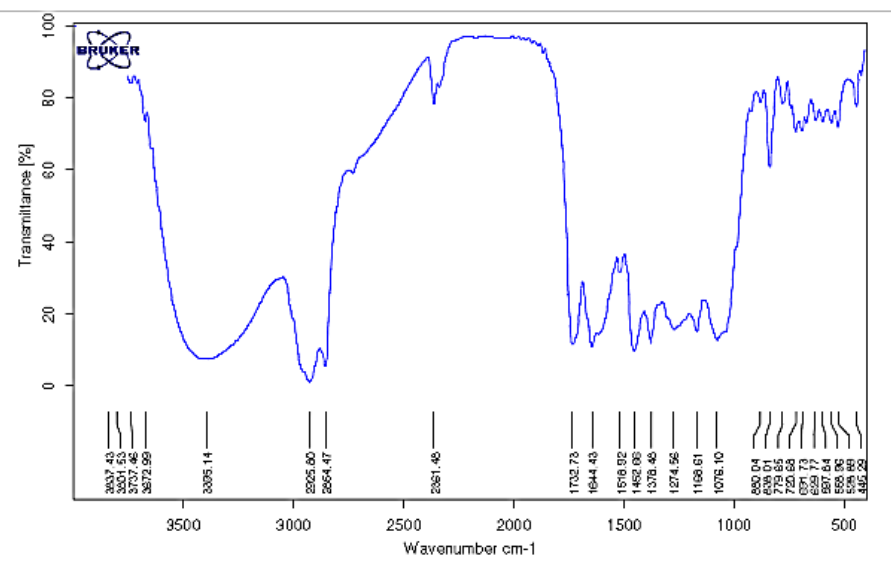

Figure 8: FTIR Spectra of leaves Garcinia daedalanthera Extract.

bial contamination. ${ }^{17}$ The moisture content of Garcinia daedalanthera extract is $2.35 \%$. The extractive values obtained revealed that majority of the chemical constituents were water-soluble not alcohol soluble. The phytochemical analysis of GDE revealed the presence of flavonoids, saponins, tannin, steroids and phenols. Flavonoids are natural biological response modifiers because of their ability to modify the body's reaction to allergy, viruses and carcinogens. They are renowned for their free radical scavenging potency, which underlines their antibacterial, antiinflammatory, anti-thrombotic and vasodilatory activities. ${ }^{18}$ Total flavonoids in Garcinia daedalanthera is $15.49 \mathrm{mg}$ QE/g. Flavonoids are known to show antioxidant activity having considerable effects on human nutrition and health. The mechanism of flavonoid action is based on scavenging or chelating process. ${ }^{19}$ We assume that the antioxidant activity which has been proven by previous research might from its high contents of flavonoid-type compounds. The detection of phenolic contents in the preliminary phytochemical investigation of the drug plant and ethanolic extract led to their quantification. Total phenolic content of GDE is 55.13 GAE/g which means GDE contains high of phenolic compounds. Some 
authors reported relationship between the antioxidant activity and the total phenolic content whereas others found no such correlation, so the total phenolic content does not represent all antioxidant compounds in the extract, which can explain the unclear relationship between the total phenolic content and the antioxidant capacity. ${ }^{20}$ Total tannin of GDE is 7.21 TAE /g which means GDE has a few of tannins content than flavonoids or phenolic content. tannins can have an inhibitory effect due to the reduction of enzyme Activity. ${ }^{21}$ We assume the activity of a-glucosidase inhibitor compounds derived from tannin. The metal analysis of extract Garcinia daedalanthera showed the presence of $\mathrm{Pb}$ and As under limit detection, the presence of $\mathrm{Cd}$ and Fe are $0.008 \mathrm{ppm}$ and $16.95 \mathrm{ppm}$. The quantity of these metals in the extract sample revealed that they are well below tolerable upper intake level. Contaminant analysis showed that Garcinia daedalanthera extract has no contaminant of E. Coli, Salmonella sp, Pseudomonas aeruginosa. FTIR result showed the presence of carboxylic acid, alkanes, phenol and C-H (aldehydes). Based on FTIR, the extract contains 26 peaks. All FTIR data will be correlated in future with the detailed HPLC analysis of the same extract and compare with the standard of the extract to investigate the fingerprint and to evaluate the quality and authenticity of formulating herbicidal potential.

\section{CONCLUSION}

In conclusion, the data generated from this study would help in standardization for pharmacopoeial and prevent adulteration of leaves extract of Garcinia daedalanthera Pierre. The preliminary phytochemical screening of leaves extract of Garcinia daedalanthera Pierre indicates the presence of secondary metabolites has an essential role in medicine. Further, the authentic plant material can be developed for its pharmacological.

\section{ACKNOWLEDGEMENT}

The author thanks to Hibah Pitta Grant UI for funding this research, also sincerely thanks to laboratory of Pharmacognosy Faculty of Pharmacy Indonesia University and Laboratorium Pusat Studi Biofarmaka Tropika-LPPM IPB for providing facilities.

\section{CONFLICT OF INTEREST}

The authors have no conflict of interest to declare.

\section{ABBREVIATION USED}

FTIR: Fourier Transform Infrared Spectroscopy; GDE: Garcinia daedalanthera extract; GD: Garcinia daedalanthera; Cd: Cadmium; HPLC: High Performance Liquid Chromatography; QE: Quercetin equivalent.

\section{REFERENCES}

1. Woerdenbag HJ, Kayser O. Jamu: Indonesian traditional herbal medicine towards rational phytopharmacological use. Perspect Med. 2014;4(2):51-73.
2. Lahrita L, Kato E, Kawabata J, Jack E, Piper L. Uncovering potential of Indonesian medicinal plants on glucose uptake enhancement and lipid suppression in 3T3-L1 adipocytes. J Ethnopharmacol. 2015;168:229-36.

3. Fatmawati S, Ersam T, Shimizu K. Phytomedicine The inhibitory activity of aldose reductase in vitro by constituents of Garcinia mangostana Linn. Phytomedicine. 2015;22(1):49-51.

4. Jamila $N$, Khairuddean $M$, Khan $S N$, Khan N Complete NMR assignments of bioactive rotameric (3-8) biflavonoids from the bark of Garcinia hombroniana. Magnetic Resonance in Chemistry. 2014;52:345-52. doi:10.1002/ mrc.4071 available from : http://onlinelibrary.wiley.com/doi/10.1002/mrc.4071/epdf

5. Yousif M, Mohd N, Mariod AA, Mohan S, Ameen M, Ibrahim S. a -Mangostin from Garcinia mangostana Linn : An updated review of its pharmacological properties. Arab J Chem. 2016;9(3):317-29.

6. Elya B, Basah K, Mun A, et al. Screening of $\alpha$-Glucosidase Inhibitory Activity from Some Plants of Apocynaceae, Clusiaceae, Euphorbiaceae, and Rubiaceae. 2012;2012.

7. Kurniasari D. Isolasi dan Identifikasi Senyawa Antioksidan dan Penghambat Alpha Glucosidase dari Ekstrak Etil Asetat Daun Garcinia daedalanthera Pierre. Thesis, Faculty of Pharmacy, Uviersitas Indonesia. 2016.

8. Petchi RR, Vijaya C, Parasuraman S. Antidiabetic activity of polyherbal formulation in streptozotocin - nicotinamide induced diabetic wistar rats. J Tradit Complement Med. 2014;4(2):108-17.

9. Iqbal E, Abu K, Lim LBL. Phytochemical screening, total phenolics and antioxidant activities of bark and leaf extracts of Goniothalamus velutinus ( Airy Shaw ) from Brunei Darussalam. J King Saud Univ-Sci. 2015;27(3):224-32.

10. LiY, Ding P, Huang C, Lu S. Acta Ecologica Sinica Total tannin content of foods of François ' Langur in Fusui, Guangxi, China : Preliminary study. Acta Ecol Sin. 2015;35(1):16-22

11. AOAC : Official Method of Analytical Chemistry. Vol 1. 16 $6^{\text {th }}$ Edition. 1999. Washington. U.S.A

12. Alexei YB, Joseph IS, Olga VF. Endogenous cardiotonic steroids: physiology, pharmacology and novel therapeutic targets. Pharmacol. 2009;61:9-38.

13. Kumari M, Jain S. Tannins : An Antinutrient with Positive Effect to Manage Diabetes. Res J Recent Sci. 2012;1(12):70-3.

14. Bunghez F. Application of FT-IR Spectroscopy for Finger printing Bioactive Molecules in a Nutraceutical PROMEN, comparatively with Plantingredients. Food Sci Technol. 2013;70(1):68-69. http://journals.usamvcluj.ro/index.php/fst/article/ viewFile/9720/7936

15. Sandhya S, Venkatramana K, Vinod KR, et al. Pharmacognostical Standardization of Tephrosia maxima Pers Root. Pharmacogn J. 2011;3(26):25-33.

16. Cheng D, Zhang $Y$, Xin $X$, Gao D. Comparative pharmacognosy of Pyrrosia petiolosa and Pyrrosia davidii. Brazilian J Pharmaacognosy. 2014;24(4):368-80.

17. E SP, Venkataraman S. Pharmacognostical And Phytochemical Studies Of Strychnos Potatorum Linn Seeds. Pharmacogn J. 2010;2(8):190-7.

18. Hosu A, Cristea V, Cimpoiu C. Analysis of total phenolic, flavonoids, anthocyanins and tannins content in Romanian red wines : Prediction of antioxidant activities and classification of wines using artificial neural networks. FOOD Chem. 2014; 150:113-8

19. Suhartono E, Viani E, Apriyansa M, Syahuri I. Total flavonoid and Antioxidant Activity of Some Selected Medicinal Plants in South Kalimantan of Indonesian. 2012;4:235-9.

20. Metrouh-amir H, Duarte CMM, Maiza F. Solvent effect on total phenolic contents, antioxidant, and antibacterial activities of Matricaria pubescens. Ind Crop Prod. 2015;67:249-56

21. LiY, Ding P, Huang C, Lu S. Acta Ecologica Sinica Total tannin content of foods of François ' Langur in Fusui, Guangxi, China : Preliminary study. Acta Ecologica Sinica. 2015;35(1):16-22.

22. DK G, Ld P. Pharmacognostical Studies of Bauhinia variegata Linn root. J Young Pharm. 2009;1(1):36-41 